ORIGINAL ARTICLE

\title{
Paeonia lactiflora improves ovarian function and oocyte quality in aged female mice
}

Min Jung Park ${ }^{1}$, Si-Eun Han² (D), Hyeon Jeong Kim¹ (D), Jeong doo Heo ${ }^{3}$, Hee-Jung Choi ${ }^{4}$, Ki-Tae Ha $^{4}$ (D), Sun Woo Yang ${ }^{(1 D}$, Kyu Sup Lee ${ }^{2}$, Seung Chul Kim² (D), Chang Woon Kim5 (D), Bo Sun Joo ${ }^{1,4 *}$ (D)

\author{
${ }^{1}$ The Korea Institute for Public Sperm Bank, Busan, Repuplic of Korea \\ ${ }^{2}$ Department of Obstetrics and Gynecology, Pusan National University School of Medicine, Busan, Repuplic of Korea \\ ${ }^{3}$ Korea Institute of Toxicology, Jinju, Gyeongsangnam-do, Republic of Korea \\ ${ }^{4}$ Healthy Aging Korean Medical Research Center, Pusan National University School of Korean Medicine, Yangsan, Republic of \\ Korea \\ ${ }^{5}$ Department of Obstetrics and Gynecology, Samsung Changwon Hospital, Sungkyunkwan University School of Medicine, \\ Changwon, Korea, Republic of Korea
}

How to cite: Park MJ, Han SE, Kim HJ, Heo J, Choi HJ, Ha KT, Yang SW, Lee KS, Kim SC, Kim CW, Joo BS. Paeonia lactiflora improves ovarian function and oocyte quality in aged female mice. Anim Reprod. 2020;17(2):e20200013. https://doi.org/10.1590/1984-3143-AR2020-0013

\begin{abstract}
Although ovarian aging is a key cause of decreased ovarian function and oocyte quality, it remains a problem in infertility treatment. Therefore, this study is aimed to investigate whether Paeonia lactiflora $(\mathrm{PL})$, a herb improves ovarian function and oocyte quality using aged female mice. C57BL/6 female mice aged 8 months were treated orally every day with PL of $26.5 \mathrm{mg} / \mathrm{kg}(\mathrm{n}=7)$ and $53 \mathrm{mg} / \mathrm{kg}(\mathrm{n}=7)$ of body weight for 4 weeks using an oral zoned needle. The control group $(n=7)$ was treated with normal saline. Ovaries and serum were collected for the H\&E stain and the evaluation of reactive oxygen species (ROS) levels, respectively. In the second experiment, female mice were orally administered with $\mathrm{PL}$ ( $26.5 \mathrm{mg} / \mathrm{kg}: \mathrm{n}=12,53 \mathrm{mg} / \mathrm{kg}: \mathrm{n}=12$, control: $\mathrm{n}=12$ ) and then superovulated with PMSG and hCG, and mated with male mice. Zygotes were retrieved and cultured for 4 days. Ovaries were provided for examination of expressions of genes associated with angiogenesis (VEGF and visfatin), anti-aging (Sirt1 and Sirt2), and follicular development (c-Kit, BMP-15, and GDF-9). PL significantly increased numbers of surviving follicles (primordial, primary, secondary, and antral), numbers of zygotes retrieved, embryo development rate, and ovarian expression of VEGF, visfatin, c-Kit, BMP-15, and GDF-9 at both doses. However, ovarian expression of Sirt1 and Sirt2 was increased at $53.0 \mathrm{mg} / \mathrm{kg}$ of PL. ROS levels were not affected by PL. These results suggest that PL may possess beneficial effects regarding ovarian function and oocyte quality, possibly by activation of ovarian angiogenesis and follicular development.
\end{abstract}

Keywords: ovarian aging, Paeonia lactiflora, ovarian function, oocyte quality.

\section{Introduction}

Recently, age-related decline in fertility is becoming a significant issue in infertility treatment because more women are delaying marriage or childbearing. Advanced female age causes ovarian aging, finally resulting in decreased ovarian function and oocyte quality (Broekmans et al., 2007; Steiner et al., 2017; Duncan and Gerton, 2018). Age-related ovarian aging cannot be recovered and it remains a problem in infertility treatment. Nevertheless, several strategies have recently attempted to improve reproductive capacity with age (Ha et al., 2010; Choi et al., 2012; Celik et al., 2015; Özcan et al., 2016).

*Corresponding author: bosunjoo@hanmail.net

Received: February 21, 2020. Accepted: June 1, 2020.

Financial support: This study was supported by a grant from the National Research Foundation of Korea (NRF) funded by the Ministry of Science, ICT \& Future Planning (MISP), of the Korean Government (Grant $n^{\circ}$. 2014R1A5A20009936), and by a grant from the National Research Foundation of Korea (NRF) grant funded by the Korea government (MSIT) ( $n^{\circ}$. 2017R1C1B2012624).

Conflicts of interest: The authors have no conflict of interest to declare.

(i) Copyright (c) The Author(s). This is an Open Access article distributed under the terms of the Creative Commons Attribution License, which permits unrestricted use, distribution, and reproduction in any medium, provided the original work is properly cited. 
The deterioration of oocyte quality with age is mainly due to mitochondrial dysfunction via a decrease in cellular function of the oocytes (Thouas et al., 2005; May-Panloup et al., 2016). Oxidative stress is caused by mitochondrial dysfunction and finally induces aging of the cells, follicular atresia, and poor oocyte quality (Meldrum, 2013). It has been recently reported that Sirtuins, a representative anti-aging-related marker, are associated with gamete biology and reproductive physiology (Tatone et al., 2018). In this respect, the anti-oxidation and anti-aging have been proposed to improve age-related decline in oocyte quality (Bentov and Casper, 2013; Özcan et al., 2016).

As another reason for age-related decline in oocyte quality, decrease in ovarian angiogenesis has been suggested because ovarian angiogenesis plays an important role in a series of events of folliculogenesis (Geva and Jaffe, 2000; Fraser, 2006; Tatone et al., 2008). Some studies have demonstrated that the activation of ovarian angiogenesis can improve oocyte quality and ovarian function (Shimizu et al., 2003; Danforth et al., 2003; Choi et al., 2012). Angiogenesis is regulated primarily by various angiogenic factors such as vascular endothelial growth factor (VEGF), visfatin, and nitric oxide (NO) (Adya et al., 2008; Murohara et al., 1998). These factors play an important role in oocyte meiotic maturation and ovulation (Jablonka-Shariff and Olson, 1998). Although various factors regulating angiogenesis have been identified, there is no clinically effective treatment for improving oocyte quality in aged female.

The root of Paeonia lactiflora Pall. (belong to Paeoniaceae) is a herb that has traditionally being used in the treatment of gynecological disorders such as dysmenorrhea and infertility in oriental medicine of East Asian countries (Gao and Bernie, 1997; Jia et al., 2006). Our previous study showed that aqueous extract of $P$. lactiflora (PL) affects embryo implantation via increasing leukemia inhibitory factor-mediating endometrial receptivity (Choi et al., 2016). A combination of PL and Glycyrrhiza glabra extract was effective in normalizing menstrual cycles and hormonal balance in the patients with polycystic ovarian syndrome (PCOS) (Ushiroyama et al., 2001). Paeoniflorin extracted from PL extract improves ovulation in women with PCOS by reducing androgen production in theca cells (Ong et al., 2019). It also has various physiological effects including anti-inflammatory, anti-oxidation, and anti-aging (He and Dai, 2011; Chen et al., 2018).

However, there are no reports on the effects of PL on ovarian function and oocyte quality, especially for reproductive aged female. PL is being clinically used to treat gynecological problems including infertility in oriental medicine at a dose of $16 \mathrm{~g}$ per day for adult women weight $60 \mathrm{~kg}$. This dosage is about $53 \mathrm{mg} / \mathrm{kg}$, considering 20\% of recovery rate of PL extraction. Therefore, this study determined $53 \mathrm{mg} / \mathrm{kg}$ and half as $26.5 \mathrm{mg} / \mathrm{kg}$ as the treatment concentration of $\mathrm{PL}$, and investigated whether oral administration of $\mathrm{PL}$ improves ovarian function and oocyte quality in aged female mice.

\section{Methods}

This study was approved by the Institutional Review Board of Pusan National University Hospital, Korea. All animal experiments were conducted under the guidance for the Care and Use of Laboratory Animals of the National Institutes of Health, approved by the Pusan National University Hospital Institutional Animal Care and Use Committee (Approval number: PNUH-2019-148).

\section{Animals}

This study used inbred C57BL/6 mice in all experiments. The mice were purchased from the Koatech Inc. (Gyunggi-do, Korea) and bred under a 12 hours light/dark cycle with free access to water and food in an animal facility of SPF class with a temperature of $21 \pm 2{ }^{\circ} \mathrm{C}$ and the relative humidity of $55 \% \pm 10 \%$. 


\section{Preparation of PL}

The PL used in this study was an identical sample prepared with our previous study (Choi et al., 2016). Briefly, the roots of P. lactiflora were purchased from Omniherb Co. (Daegu, Korea) cultivated field in Gyeongsangbuk-do Province, Korea in 2013. The plant was identified by a botanical expert working at Omniherb (Daegu, Korea). A boucher specimen (DC-H21) was authenticated by HPLC analysis with several standard compounds including gallic acid, catechin, methyl gallate, paeoniflorin, and benzoic acid, and deposited in Korean Medical Research Center for Healthy Aging, Pusan National University (Busan, Korea). The roots of $P$. lactiflora $(100 \mathrm{~g}$ ) were extracted with 1 liter of distilled water for 2 hours at $100{ }^{\circ} \mathrm{C}$, and then centrifuged at $4000 \mathrm{rpm}$ for 10 minutes.

\section{Treatment of PL}

C57BL/6 female mice aged 8 months were randomly divided into three groups ( $\mathrm{n}=7$ per group): one control group and two PL treatment groups. PL was administered orally every day using syringes with an oral zoned needle at doses of $26.5 \mathrm{mg} / \mathrm{kg}$ and $53.0 \mathrm{mg} / \mathrm{kg}$ of body weight/150 $\mu \mathrm{L}$ for 4 weeks. The control group was treated with the same volume of normal saline as PL treatment.

\section{Measurement of body weight and ovarian weight}

Body weights of animals were measured daily from the start of the experiment to just before sacrifice after 4 weeks of PL treatment. At the time of sacrifice, ovaries were collected, and weighed. The ovary weight index was defined by the following formula: ovary weight index=ovarian weight/body weight.

\section{Ovary and serum collection}

At the time of sacrifice, after both ovaries were carefully removed and cleaned of fat tissue, the blood was collected from heart puncture using a syringe and needle and centrifuged at $1000 \mathrm{~g}$ for 15 minutes. And then the collected sera were stored at $-80{ }^{\circ} \mathrm{C}$ until evaluation of ROS levels. The collected ovaries were weighed. Freshly dissected ovaries were divided as follows: One of the two ovaries from each mouse was immediately fixed in $4 \%$ paraformaldehyde for histopathology study, whereas the remaining tissues were immediately frozen at $-80^{\circ} \mathrm{C}$ until used for analysis.

\section{Histological Hematoxylin and Eosin (H\&E) staining and ovary follicle counting}

After 4 weeks of $\mathrm{PL}$ treatment, ovaries were fixed in $4 \%$ paraformaldehyde at $4{ }^{\circ} \mathrm{C}$ overnight, and dehydrated using ethanol series, cleared in xylene, embedded in paraffin, and sectioned for H\&E staining. Sections were observed under a light microscope. Every section from each ovary was used for follicle counting and the results were corrected for double counting. Follicles were classified as an oocyte surrounded by a partial or complete layer of squamous granulosa cells into primordial follicle (an oocyte surrounded by one layer of flattened granulosa cells), primary follicle (an oocyte surrounded by one layer of cuboidal granulosa cells), secondary follicle (two or three layers of cuboidal granulosa cells with no antral space), and antral follicle (more than four layers of granulosa cells with one or more independent antral spaces, or with a cumulus granulosa cell layer)(Luo et al., 2008). Atretic follicles were considered the presence of apoptotic bodies in the granulosa cell layer, disorganized granulosa cells, a degenerating oocyte, or fragmentation of the oocyte nucleus (Liu et al., 2015). 


\section{Superovulation, zygotes collection, and embryo culture}

In the second part of the study, 36 female mice were administered orally every day with $\mathrm{PL}$ of $26.5 \mathrm{mg} / \mathrm{kg}$ and $53.0 \mathrm{mg} / \mathrm{kg}$ of body weight $/ 150 \mu \mathrm{L}$ for 4 weeks using syringes with an oral zoned needle. The day after the final administration of $\mathrm{PL}$, the mice were superovulated by intraperitoneal injection with $0.1 \mathrm{~mL}$ of $5 \mathrm{IU}$ pregnant mare's serum gonadotropin (PMSG; Sigma-Aldrich, St Louis, MO, USA) followed by injection of $5 \mathrm{IU}$ of human chorionic gonadotropin (hCG; Sigma-Aldrich) approximately 48 hours later. Then the mice were immediately paired with an 8-12-week-old individual male. The following morning the mice were inspected, and those with a confirmed vaginal plug were considered fertilized. Eighteen hours after hCG injection, female mice with a confirmed vaginal plug were killed by cervical dislocation, and cumulus-enclosed one-cell embryos (zygotes) were retrieved from the oviductal ampulae and denuded by incubation for 1 minute with $0.1 \%$ hyaluronidase (Sigma-Aldrich) in PBS (Giboc BRL, Grand Island, NY, USA). Zygotes were pooled and washed three times in G-IVF-plus medium (Vitrolife, V. Frolunda, Sweden) with $10 \%$ serum substitute supplement (SSS; Irvine, Inc. Santana, USA). Healthy zygotes only were cultured in $20-\mu \mathrm{L}$ drops of GI-plus medium (Vitrolife) with 10\% SSS for the first 2 days, and then G2-plus medium (Vitrolife) with 10\% SSS for the latter 2 days under paraffin-oil at $37^{\circ} \mathrm{C}$ in a $5 \% \mathrm{CO} 2$ incubator, and the media were changed daily.

\section{Expression of genes associated with angiogenesis, anti-aging, and follicular development in ovarian tissues}

Just after the retrieval of the zygotes, both ovaries of each mouse were collected and mRNA expressions of genes associated with angiogenesis [vascular endothelial growth factor (VEGF) and visfatin], anti-aging [Sirtuins-1 (Sirt1), and Sirt2], and follicular development [Kit ligand receptor (c-Kit), bone morphogenetic protein-15 (BMP-15), and growth differentiation factor-9(GDF-9)] were measured by quantitative real-time PCR.

\section{Quantitative PCR}

Total RNA was extracted using Trizol reagent (Invitrogen, Carlsbad, CA, USA) according to the manufacturer's protocol. Complementary DNA was synthesized from $1 \mu \mathrm{g}$ of total RNA using AMV Reverse Transcriptase (Promega, Madison, WI, USA) and a random hexamer (Takara Bio, Inc., Otsu, Japan) at $42^{\circ} \mathrm{C}$ for 1 hour by inactivation of the enzyme at $95^{\circ} \mathrm{C}$ for 5 min. Real-time PC R was performed using TOPreal ${ }^{T M}$ QPCR 2X PreMIX SYBR (Enzynomics, Daejeon, Korea). Reaction mixtures were prepared using TOPrealTM $\mathrm{qPCR} 2 \mathrm{X}$ PreMIX, $0.5 \mathrm{pmol} / \mu \mathrm{L}$ of each primer, 100ng of $\mathrm{CDNA}$, and sterile water (RNase free). The reaction conditions consisted of denaturation at $95^{\circ} \mathrm{C}$ for 10 minutes, followed by 30 cycles of $95^{\circ} \mathrm{C}$ for 10 seconds, $60{ }^{\circ} \mathrm{C}$ for 30 seconds. Each CDNA was subjected to polymerase chain reaction (PCR) amplification using gene-specific primers (Table 1). Quantitative PCR (qPCR) was carried out using LightCycle 480 SYBR Green I Master (Roche Diagnostics, Mannheim, Germany). The reaction conditions consisted of denaturation at $95^{\circ} \mathrm{C}$ for $10 \mathrm{~min}$, followed by 40 cycles of $95{ }^{\circ} \mathrm{C}$ for $10 \mathrm{~s}, 56{ }^{\circ} \mathrm{C}$ for $5 \mathrm{~s}$, and $72{ }^{\circ} \mathrm{C}$ for $20 \mathrm{~s}$. All experiments were performed in duplicate on each sample, eachbeing repeated at least three times. The relative expression levels of mRNA in each sample were calculated using the ddCt method. The level of each mRNA sample was normalized to the expression levels of the housekeeping gene GAPDH. 
Table 1. Primers sequences used for real time PCR amplification.

\begin{tabular}{ccc} 
Gene & \multicolumn{2}{c}{ Sequence $\left(\mathbf{5}^{\prime} \rightarrow \mathbf{3}^{\prime}\right)$} \\
\cline { 2 - 3 } VEGF & Forward & Reverse \\
\hline Visfatin & CT GTGCCTGCAGTGCGATAT & AGCTGCAGGTCCAGGATGTA \\
\hline c-Kit & GCCTAGTCATTGTTGCA & GCGAAGAGACTCCTCTGTAA \\
\hline BMP15 & TTGCTCCTCGTCTCTATACC & TCCACCACCCTGTTGCTGTA \\
\hline GDF9 & GAGTGTGTTGACCATTGAACC & CTAGATGGCATGGTTGG \\
\hline Sirt1 & TTGTGAAGCTGTTCGTGGAG & GCACCTCGTAGCTATCATGTC \\
\hline Sirt2 & AGCCAACCATCTGCCACTAC & GGCGTGAGGTTTTCAGTA \\
\hline GAPDH & ACCACAGTCCATGCCATCAC & TCCACCACCATCGTGTATTCTT \\
\hline
\end{tabular}

GAPDH, glyceraldehyde 3-phosphate dehydrogenase.

\section{Measurement of Reactive Oxygen Species (ROS) levels}

Serum ROS levels were measured by the OxiSelect ${ }^{\mathrm{TM}}$ In vitro ROS/RNS Assay Kit (Cell Biolabs, Inc., Sandiego, CA) following the manufacturer's instructions. Briefly, $50 \mu \mathrm{L}$ of sample and hydrogen peroxide standard was add to wells of a 96-well plate, and then $50 \mu \mathrm{L}$ of Catalyst was additional added to each well. The wells were mixed and incubated for 5 minutes at room temperature. Then, $100 \mu \mathrm{L}$ of DCFH solution was added to each well. The plate reaction wells were covered to protect them from light and incubated at room temperature for 15-45 minutes. The fluorescence of sample was read at $480 \mathrm{~nm}$ excitation/530 $\mathrm{nm}$ emission with a fluorescence plate reader.

After ovaries were weighted quickly, the tissues were homogenized on ice with $0.8 \%$ ice-cold saline at a ratio of 1:9 (w/v). Then the homogenates were centrifuged for $10 \mathrm{~min}$. Supernatants were collected for following detection. Total antioxidant capacity (TAC) was evaluated by quantitative colorimetric measurements in serum using the TAC Assay Kit (MyBioSource, San Diego, CA, USA) as per manufacturer's instructions.

\section{Statistical analysis}

An SPSS program (ver. 12.0) was used for statistical analysis. Statistical analysis for comparison of follicle counts, ovarian mRNA expression of each gene, serum ROS level, and the number of zygotes retrieved was performed by Student t-test. Embryo development rate to blastocyst were analyzed by one-way analysis of variance with post hoc multiple comparisons by Bonferroni-Dunn analysis. A $\mathrm{P}$ value of $<.05$ was considered statistically significant.

\section{Results}

\section{Effect of PL on body and ovarian index}

The body weights of all mice were recorded each day from the start of the experiment to just before sacrifice after 4 weeks of PL treatment. No changes in eating, drinking, fur color, and exploratory behavior has been observed during PL treatment. The body weight was increased normally and no difference was observed between control and PL-treated groups $(p>0.05$; Figure 1A). The ovary weight and the organ index of ovary were also not significantly different between the control and treated groups (Figure 1B). 
$\mathbf{A}$

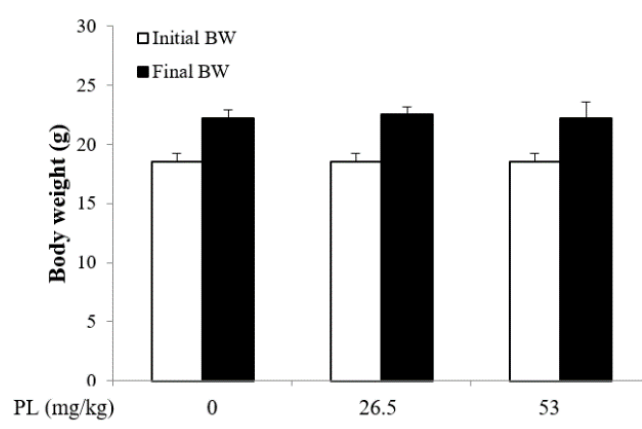

B

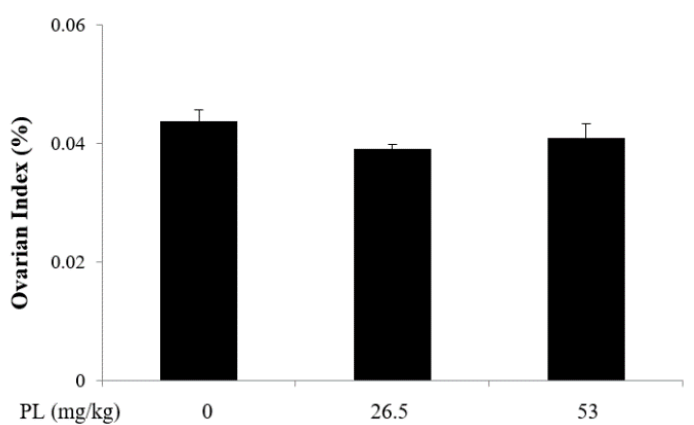

Figure 1. Effect of PL on body and ovary weights. After female mice were administrated 26.5, and $53 \mathrm{mg} / \mathrm{kg}$ of $\mathrm{PL}$ for 4 weeks, body and ovary were weighed, and the data was presented as the mean \pm SD. (A) The body weight of mice in each groups $(n=7)$; $(B)$ The ovarian index $(n=7)$. Ovarian index were calculated as ovarian weight/final body weight just before sacrifice. BW: body weight.

\section{PL improved ovarian function in natural ovarian aging mice}

The histological characteristics of follicles at each stage after PL treatment were shown in Figure 2A and mainly composed of surviving follicles (primordial, primary, secondary, and antral follicles), corpora lutea, and atretic follicles. The total number of follicles was defined as the sum of the number of all stages of follicles in one ovary. The H\&E stained ovarian tissues showed that $\mathrm{PL}$ increased the total number of follicles $(368 \pm 1.4$ at $26.5 \mathrm{mg} / \mathrm{kg}$ and $365 \pm 2.2$ at $53.0 \mathrm{mg} / \mathrm{kg}$ ) compared with the control group (290 \pm 0.8 ) with an increase rate of $26.9 \%$ at $26.5 \mathrm{mg} / \mathrm{kg}$ and $25.9 \%$ at $53.0 \mathrm{mg} / \mathrm{kg}$. Of these, numbers of surviving follicles in the PL treatment group were $322 \pm 1.2$ at $26.5 \mathrm{mg} / \mathrm{kg}$ dose and $308 \pm 2.9$ at $53.0 \mathrm{mg} / \mathrm{kg}$ dose, which was significantly more than that of the control group (213 \pm 0.9 ). The increasing rates were $51.2 \%$ at $26.5 \mathrm{mg} / \mathrm{kg}$ and $44.6 \%$ at $53.0 \mathrm{mg} / \mathrm{kg}$. In contrast, numbers of atretic follicles were $19 \pm 1.7$ at $26.5 \mathrm{mg} / \mathrm{kg}$ of PL and $33 \pm 1.7$ at $53.0 \mathrm{mg} / \mathrm{kg}$ dose, which was less than that of the control group (45 \pm 1.7$)$, with $\mathrm{d}$ decrease rate of $48.9 \%$ and $26.7 \%$, respectively (Figure $2 \mathrm{~B}$ ). The number of primordial follicles in the PL treatment group was $119 \pm 1.1$ at $26.5 \mathrm{mg} / \mathrm{kg}$ and $117 \pm 1.8$ at $53.0 \mathrm{mg} / \mathrm{kg}$, which was significantly more than that of the control group $(100.0 \pm 0.8)$. The number of primary follicles in the PL treatment group was $98.0 \pm 4.4$ at $26.5 \mathrm{mg} / \mathrm{kg}$ and $85.0 \pm 3.2$ at $53.0 \mathrm{mg} / \mathrm{kg}$, which was significantly more than that of the control group $(51.0 \pm 1.8)$. Numbers of secondary and antral follicles were significantlyincreasedjust at $26.5 \mathrm{mg} / \mathrm{kg}$ of PL $(78.0 \pm 3.2$ and $27.0 \pm 1.6$,

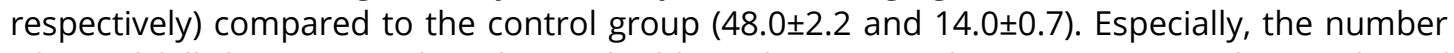
of antral follicles increased to almost double in the $26.5 \mathrm{mg} / \mathrm{kg}$ PL treatment. The number of corpora luteahad no significant difference was similar in control group and the PL treatment groups (Figure $2 \mathrm{C}$ ). 
$\mathbf{A}$

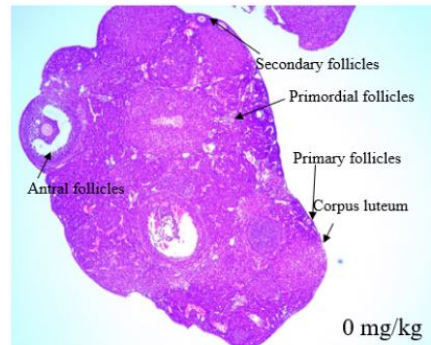

B

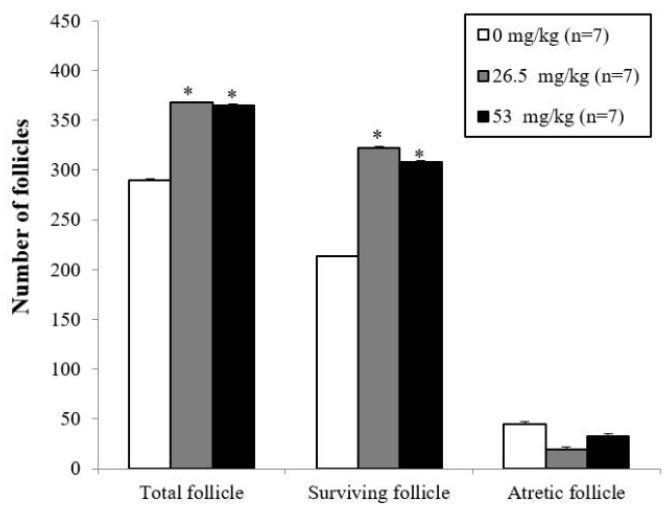

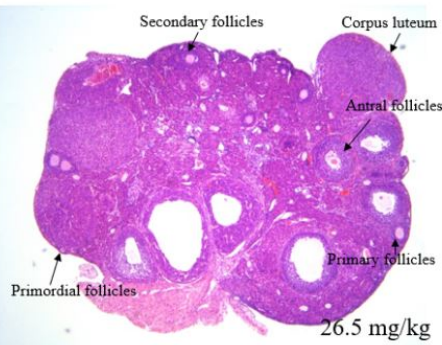

C

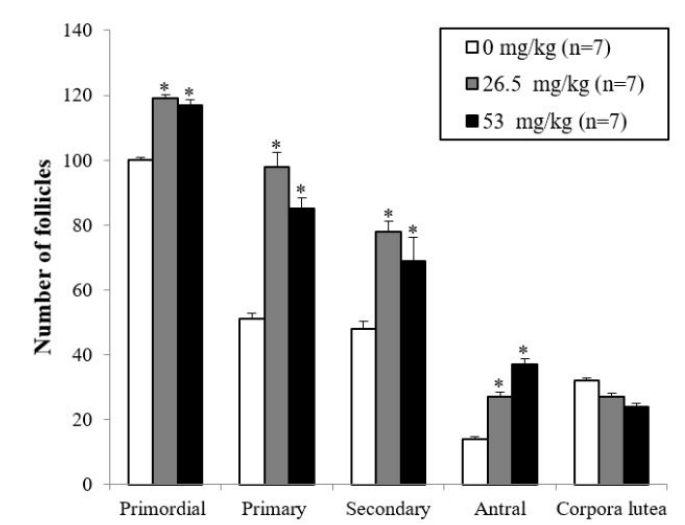

Figure 2. Effect of PL on follicular development. (A) Representative hematoxylin and eosin stained histological images of mouse ovary after water-extracted PL; $(B)$ Comparison of the total number of follicles, surviving follicles, and atretic follicles; (C) Numbers of primordial, primary, secondary, and antral follicles. Data for the number of each follicle were the mean \pm SD of all samples of each mouse. ${ }^{*} P<0.05$ (vs control group).) ( $\mathrm{n}=7$ each group).

PL significantly increased by about twice the number of zygotes retrieved to 21.5 and 22.3 at $26.5 \mathrm{mg} / \mathrm{kg}$ and $53.0 \mathrm{mg} / \mathrm{kg}$, compared with 10.8 of control group $(P<0.05)$. The embryo development rate to blastocyst was also significantly higher in PL treatment group (37.6\% at $26.5 \mathrm{mg} / \mathrm{kg}$ and 30.8 at $53.0 \mathrm{mg} / \mathrm{kg}$ ) compared to the control group (6.6\%), but there was no significant difference between PL treatment groups (Table 2).

Table 2. Effect of PL on number of zygotes retrieved and embryo development.

\begin{tabular}{cccccccc}
$\begin{array}{c}\mathbf{P L} \\
(\mathbf{m g} / \mathbf{k g} \\
\text { of BW) }\end{array}$ & $\begin{array}{c}\text { No. of } \\
\text { mice } \\
\text { provided }\end{array}$ & $\begin{array}{c}\text { No. of } \\
\text { zygotes } \\
\text { retrieved }\end{array}$ & $\begin{array}{c}\text { Mean no. of } \\
\text { zygotes } \\
\text { retrieved } \\
\text { /mouse }\end{array}$ & $\begin{array}{c}\text { No. of } \\
\text { zygotes } \\
\text { fragmented } \\
(\%)\end{array}$ & $\begin{array}{c}\text { No. of } \\
\text { zygotes } \\
\text { cultured }\end{array}$ & $\begin{array}{c}\text { No. of } \\
\text { 2-cell } \\
\text { embryos } \\
(\%)\end{array}$ & $\begin{array}{c}\text { No. of } \\
\text { blastocysts } \\
(\%)\end{array}$ \\
\hline 0 & 12 & 127 & $10.8 \pm 3.2$ & $51(40.2)$ & 76 & $36(47.4)$ & $5(6.6 \%)$ \\
\hline 26.5 & 12 & $263^{\mathrm{a}}$ & $21.5 \pm 6.1^{\mathrm{a}}$ & $42(16.0)^{\mathrm{a}}$ & 221 & $144(65.2)^{\mathrm{a}}$ & $83(37.6)^{\mathrm{a}}$ \\
\hline 53.0 & 12 & $267^{\mathrm{a}}$ & $22.3 \pm 3.5^{\mathrm{a}}$ & $46(17.2)^{\mathrm{a}}$ & 221 & $135(61.1)$ & $68(30.8)^{\mathrm{a}}$ \\
\hline $\mathrm{a} P<0.05$ (vs controls). BW: body weight
\end{tabular}

a $P<0.05$ (vs controls). BW: body weight.

\section{PL increased ovarian expression of genes associated with angiogenesis, anti-aging, and follicular development}

Expressions of VEGF and visfatin were significantly increased after PL treatment compared to the control group $(P<0.05)$. In particular, expressions of these genes were further increased at dose of $53.0 \mathrm{mg} / \mathrm{kg}$ than at dose of $26.5 \mathrm{mg} / \mathrm{kg}(\mathrm{P}<0.01)$. Also, PL treatment significantly increased the expression of C-Kit, BMP-15, and GDF-9, which have been well known to play important roles in follicular development and ovarian aging. Expressions of these genes were also higher at $53.0 \mathrm{mg} / \mathrm{kg}$ than at $26.5 \mathrm{mg} / \mathrm{kg}$ of PL ( $<<0.01$ ). Expressions of BMP-15, and GDF-9 were relatively increased more than c-Kit expression. Expressions of Sirt1 and Sirt2 were significantly increased only at $53 \mathrm{mg} / \mathrm{kg}$ of PL ( $\mathrm{P}<0.05)$ compared to the control group (Figure 3 ). 


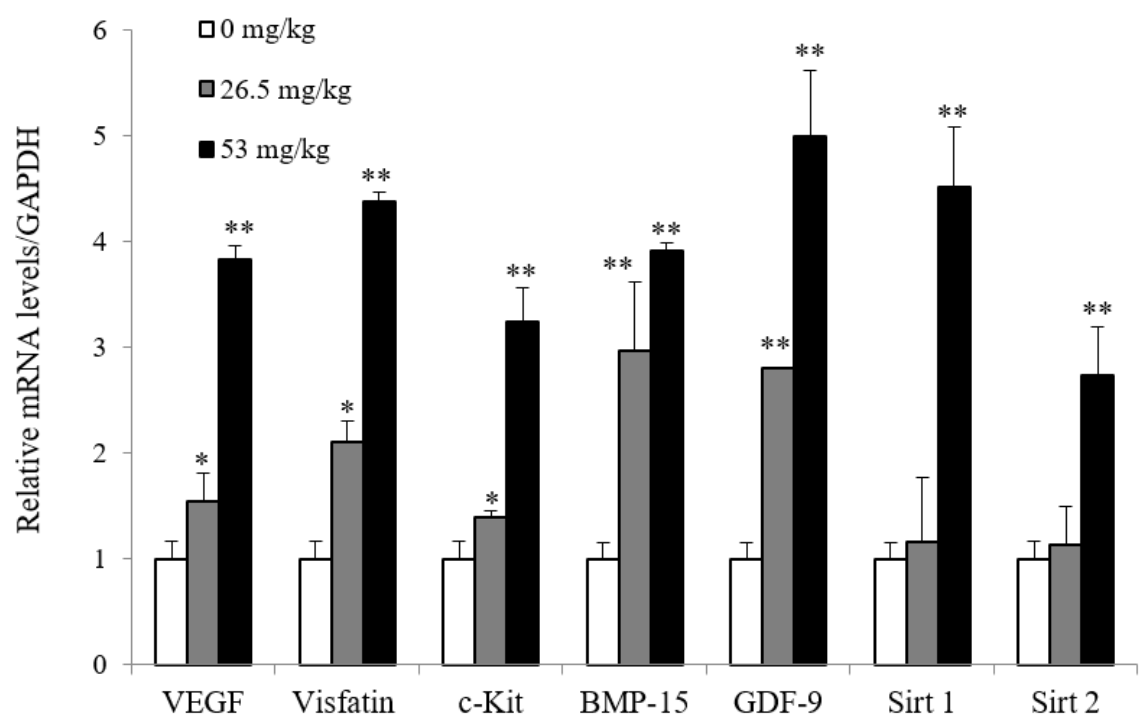

Figure 3. Expression of angiogenesis (VEGF and visfatin), anti-aging (Sirt1 and Sirt2), and folliculogenesis (c-Kit, BMP-15, and GDF-9)-related genes determined by quantitative real-time PCR. Whole ovaries were collected just after the retrieval of the zygotes. PCR was performed in duplicate on each sample. Relative gene expression levels were calculated versus GAPDH. Data are presented as mean \pm SD. ${ }^{\star} P<.05$ (vs control); $* \star P<.01$ (vs control).

\section{Effect of PL on oxidative stress}

Serum ROS levels were similar among control and PL treatment groups regardless of dose of PL (Figure 4A). Total antioxidant capacity in the treatment of PL group was slightly increased compared with the control group, but revealed no significant difference (Figure 4B). It was suggested that PL had no effect on the generation or reduction of oxidative stress in aged ovary.

$\mathbf{A}$

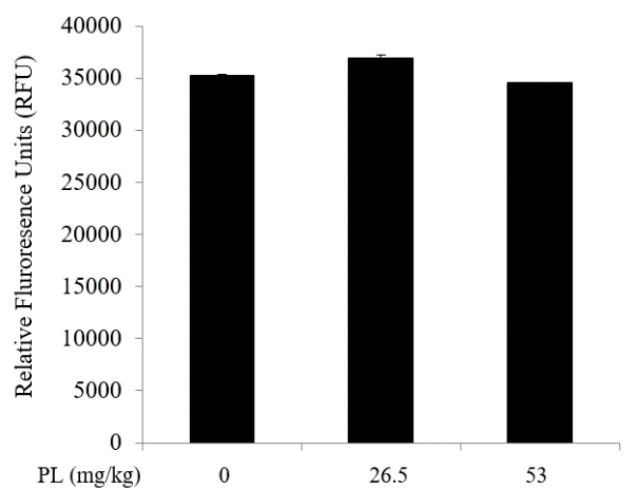

B

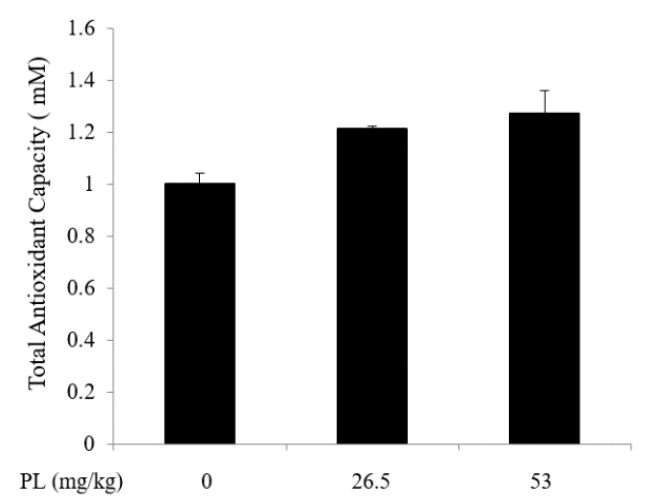

Figure 4. Effect of PL on reactive oxygen species (ROS) level. (A) Serum ROS production after 4 weeks of PL treatment. Data are given as Relative Fluorescence Units (RFU) \pm SD of two duplicate processes in two separate experiments; (B) Change of total antioxidant capacity (TAC) in ovarian tissues after treatment of $P L$. Data are presented as mean $\pm S D$ ( $n=7$ each group).

\section{Discussions}

The present study showed that PL treatment increases not only the number of surviving follicle from primary follicles to antral follicles, but also the number of retrieved zygotes and embryo development competency. This study used female mice aged 8 months, which corresponds to the early 40 s of humans (Age Converter, 2020). Since that age, the number of 
follicles and ovarian function begin to decrease rapidly. These results firstly demonstrated that PL can improve ovarian function and oocyte quality to withstand ovarian aging.

The exact mechanism for the beneficial effect of PL in aged mice remains to be elucidated. However, several possibilities can be considered. First is the activation of primordial follicles and ovarian angiogenesis by PL. The activation of dormant primordial follicles can continue to provide developing follicles and fertilizable oocytes for the entire reproductive lifespan (McGee and Hsueh, 2000). Many studies have suggested that ovarian function and oocyte quality can be improved through the activation of primordial follicles and ovarian angiogenesis (Ha et al., 2010; Celik et al., 2015; Li et al., 2010).

Ovarian angiogenesis plays a crucial role in a series of events of follicular development and follicular growth (Geva and Jaffe, 2000; Fraser, 2006). Indeed, increased vascular density is highest in mature follicles (Zelezni et al., 1981). Oocytes from poorly vascularized follicles developed in morphologically inferior embryos as compared to those from well-vascularized follicles, indicating that vascularization of the follicles can be a potential marker for the developmental potential of an embryo (Nargund et al., 1996). Dysregulation of VEGF may attenuate follicular or oocyte maturation by stimulating AMHR2 overexpression, which increases AMH binding (Fang et al., 2016). These results suggest that ovarian angiogenesis is very deeply involved in oocyte maturation process.

The activation of primordial follicles and follicular development are regulated by various intracellular signaling pathways and intraovarian factors such as VEGF, BMP series, GDF-9, and c-Kit (Paulini and Melo, 2011; Hsueh et al., 2015). Especially, GDF-9 and BMP-15 play a critical role in early follicular development and ovarian function (Paulini and Melo, 2011; Chang et al., 2016). As expected, the present study showed that PL increased the expression of VEGF, visfatin, GDF-9 and BMP-15, which were genes associated with angiogenesis and follicular development.

Second is the delay or restoration of aging itself by PL because some studies reported a potential activity of anti-aging of PL by scavenging active oxygen (Chen et al., 2018). Sirtuins has been well known to be associated with aging and longevity as a family of NAD+dependent deacetylase (Vachharajani et al., 2016; Grabowska et al., 2017). Recently, it has reviewed that Sirtuins play an important role in gamete biology and reproductive physiology (Tatone et al., 2018). Among them, Sirt1 and Sirt2 are associated with oocyte maturation (De La Fuente, 2006; Luciano et al., 2014), and suppression of ovarian aging by preserving primordial follicles (Liu et al., 2013; Zhou et al., 2014; Chen et al., 2015). In this reason, we investigated changes in expression of Sirt1 and Sirt2 genes in the ovary after PL treatment. Their mRNA expression was significantly increased only by $53 \mathrm{mg} / \mathrm{kg}$ of $\mathrm{PL}$, but at $26.5 \mathrm{mg} / \mathrm{kg}$.

Third possible mechanism is the reduction of oxidative stress-induced ovarian aging by PL because some components of $\mathrm{PL}$, such as anthocyanin and flavonoid, and phenolic compound, have antioxidant properties (Lee et al., 2017; Yang et al., 2018). In addition, quercetin, a bioflaconoid widely found in many leave and fruits, protects age-related decline in ovarian function by decreasing oxidative stress (Wang et al., 2018). However, the present study showed that ROS levels had no difference between PL treatment and control groups in serum or tissue samples, suggesting that PL in the present study had no antioxidant effect.

These results suggest that stimulation of ovarian angiogenesis and follicular development, and the inhibition of ovarian aging may increase oocyte quality, resulting in improvement of oocyte competence for embryo development. However, what was unexpected that improvement of oocyte quality and increase in the number of surviving follicles were slightly increased at $26.5 \mathrm{mg} / \mathrm{kg}$ of $\mathrm{PL}$ compared to $53.0 \mathrm{mg} / \mathrm{kg}$ without significance, whereas the expressions of genes associated with angiogenesis (VEGF and visfatin), follicular development (BMP-15, GDF-9), and anti-aging (Sirt1 andSirt2) were significantly increased at $53.0 \mathrm{mg} / \mathrm{kg}$ of $\mathrm{PL}$ compared to $26.5 \mathrm{mg} / \mathrm{kg}$. This result means that the concentration on gene expression and the concentration on egg quality and follicle development through gene products are not necessarily parallel. This means that although gene expression is promoted at high concentrations, egg quality and follicular development can be sufficiently improved by gene products expressed at low concentrations. 
The most difficult point in starting this study was to determine the treatment concentration of PL. To determine an optimal concentration, our study group previously tested the cytotoxic effect of PL on Ishikawa cells (Choi et al., 2016). PL did not show significant cytotoxicity up to a concentration of $100 \mu \mathrm{g} / \mathrm{mL}$ of high concentration. Second, $\mathrm{PL}$ is being clinically used to treat gynecological problems including infertility in oriental medicine at a dose of $16 \mathrm{~g}$ per day for adult women weight $60 \mathrm{~kg}$ for 4 weeks. This dosage is about $53 \mathrm{mg} / \mathrm{kg}$, considering 20\% of recovery rate of PL extraction. In several previous in vivo studies, PL was administered for 14-38 days (Lee et al., 2005; Li et al., 2012; Wu et al., 2014). Therefore, this study determined $53 \mathrm{mg} / \mathrm{kg}$ and half as $26.5 \mathrm{mg} / \mathrm{kg}$ as the treatment concentration of PF for 4 weeks. These concentrations are similar to the concentrations used in other study on the protection of liver injury by PL using mice which treated PF from $25 \mathrm{mg}$ to $100 \mathrm{mg} / \mathrm{kg}$ body weight (Liu et al., 2006).

Another important value of this study is that overcoming ovarian aging can be an effective therapeutic strategy for menopausal symptoms. Hormonal replacement therapy is practically used to treat menopausal problems, but it has an increased risk of cancer or recurrence in cancer survivors. So, new researches are being needed on the development of effective method to delay or overcome natural ovarian aging and some studies have been attempted using various kinds of stem cells (Ding et al., 2018). Therefore, if PL in this study has the same effect in human studies, PL could be developed as an important remedy for solving menopausal problems.

However, one of the limitations of the present study is that this study did not reveal the critical components for the beneficial effect of PL. Likewise other plant materials, the components of $P$. lactiflora are variable by seasonal and regional changes (Kim et al., 2006; Oyungerel et al., 2017; Zhu et al., 2015). However, the Paeonia genus-specific glycosides, such as paeoniflorin, albiflorin, and 1,2,3,4,6-penta-O-galloyl- $\beta$-D-glucose, are most abundant compounds in most of crude drug samples collected from different regions or seasons (Kim et al., 2006; Parker et al., 2016; Zhu et al., 2015). Among them, paeoniflorin was reported that regulates the synthesis of steroid hormones in ovarian cells (Ong et al., 2019; Takeuchi et al., 1991). However, there are no previous studies reporting the effect of these compounds on the regulation of ovarian function and oocyte in aged mice. Therefore, further studies are needed to elucidate whether these compounds are involved in the improvement of ovarian function and oocyte quality by PL.

\section{Conclusions}

The present study shows that water-extract PL improves ovarian function, oocyte quality and oocyte embryo development competency in aged female mice. In addition, PL increases ovarian expression of angiogenic factors (VEGF and visfatin), follicular development regulatory factors (c-Kit, BMP-15, and GDF-9), and anti-aging genes (Sirt1 and Sirt2) while ROS level was not affected by PL. These results suggest that the beneficial effects of PL may be attributed to the activation of ovarian angiogenesis and follicular development, and anti-aging event. These results may contribute to the development of PL as a new treatment strategy for ovarian aging or premature ovarian failure.

\section{Acknowledgements}

This study was supported by a grant from the National Research Foundation of Korea (NRF) funded by the Ministry of Science, ICT \& Future Planning (MISP), of the Korean Government (Grant $n^{\circ}$. 2014R1A5A20009936), and by a grant from the National Research Foundation of Korea (NRF) grant funded by the Korea government (MSIT) $\left(n^{\circ} .2017 R 1 C 1 B 2012624\right)$ 


\section{References}

Adya R, Tan BK, Punn A, Chen J, Randeva HS. Visfatin induces human endothelial VEGF and MMP-2/9 production via MAPK and PI3K/Akt signaling pathways: novel insights into visfatin-induced angiogenesis. Cardiovasc Res. 2008;78(2):356-65. http://dx.doi.org/10.1093/cvr/cvm111. PMid:18093986.

Age Converter. Mouse age calculator [Internet]. 2020 [cited 2020 Feb 21]. Available from: http://www.age-converter.com/mouse-age-calculator

Bentov Y, Casper RF. The aging oocyte--can mitochondrial function be improved? Fertil Steril. 2013;99(1):18-22. http://dx.doi.org/10.1016/j.fertnstert.2012.11.031. PMid:23273985.

Broekmans FJ, Knauff EA, teVelde ER, Macklon NS, Fauser BC. Female reproductive ageing: current knowledge and future trends. Trends Endocrinol Metab. 2007;18(2):58-65. http://dx.doi.org/10.1016/j.tem.2007.01.004. PMid:17275321.

Celik O, Celik N, Gungor S, Haberal ET, Aydin S. Selective Regulation of oocyte meiotic events enhances progress in fertility preservation Methods. Biochem Insights. 2015;8:11-21. http://dx.doi.org/10.4137/BCI.S28596. PMid:26417205.

Chang HM, Qiao J, Leung PC. Oocyte-somatic cell interactions in the human ovary-novel role of bone morphogenetic proteins and growth differentiation factors. Hum Reprod Update. 2016;23(1):1-18. http://dx.doi.org/10.1093/humupd/dmw039. PMid:27797914.

Chen IC, Lin TH, Hsieh YH, Chao CY, Wu YR, Chang KH, Lee MC, Lee-Chen GJ, Chen CM. Formulated Chinese medicine shaoyao gancaotang reduces tau aggregation and exerts neuroprotection through anti-oxidation and anti-inflammation. Oxid Med Cell Longev. 2018;2018:9595741. http://dx.doi.org/10.1155/2018/9595741. PMid:30510632.

Chen Z, Kang X, Wang L, Dong H, Wang C, Xiong Z, Zhao W, Jia C, Lin J, Zhang W, Yuan W, Zhong M, Du H, Bai X. Rictor/mTORC2 pathway in oocytes regulates folliculogenesis, and its inactivation causes premature ovarian failure. J Biol Chem. 2015;290(10):6387-96. http://dx.doi.org/10.1074/jbc.M114.605261. PMid:25564616.

Choi HJ, Chung TW, Park MJ, Lee KS, Yoon Y, Kim HS, Lee JH, Kwon SM, Lee SO, Kim KJ, Baek JH, Ha KT. Paeonia lactiflora enhances the adhesion of trophoblast to the endometrium via induction of leukemia inhibitory factor expression. PLoS One. 2016;11(2):e0148232. http://dx.doi.org/10.1371/journal.pone.0148232. PMid:26839969.

Choi KH, Joo BS, Sun ST, Park MJ, Son JB, Joo JK, Lee KS. Administration of visfatin during superovulation improves developmental competency of oocytes and fertility potential in aged female mice. Fertil Steril. 2012;97(5):1234-1241.e3. http://dx.doi.org/10.1016/j.fertnstert.2012.02.032. PMid:22425197.

Danforth DR, Arbogast LK, Ghosh S, Dickerman A, Rofagha R, Friedman Cl. Vascular endothelial growth factor stimulates preantral follicle growth in the rat ovary. Biol Reprod. 2003;68(5):1736-41. http://dx.doi.org/10.1095/biolreprod.101.000679. PMid:12606430.

De La Fuente R. Chromatin modifications in the germinal vesicle (GV) of mammalian oocytes. Dev Biol. 2006;292(1):1-12. http://dx.doi.org/10.1016/j.ydbio.2006.01.008. PMid:16466710.

Ding C, Zou Q, Wang F, Wu H, Chen R, Lv J, Ling M, Sun J, Wang W, Li H, Huang B. Human amniotic mesenchymal stem cells improve ovarian function in natural aging through secreting hepatocyte growth factor and epidermal growth factor. Stem Cell Res Ther. 2018;9(1):55. http://dx.doi.org/10.1186/s13287-018-0781-9. PMid:29523193.

Duncan FE, Gerton JL. Mammalian oogenesis and female reproductive aging. Aging (Albany NY). 2018;10(2):162-3. http://dx.doi.org/10.18632/aging.101381. PMid:29410392.

Fang Y, Lu X, Liu L, Lin X, Sun M, Fu J, Xu S, Tan Y. Vascular endothelial growth factor induces anti Müllerian hormone receptor 2 overexpression in ovarian granulosa cells of in vitro fertilization/intracytoplasmic sperm injection patients. Mol Med Rep. 2016;13(6):5157-62. http://dx.doi.org/10.3892/mmr.2016.5173. PMid:27109000.

Fraser HM. Regulation of the ovarian follicular vasculature. Reprod Biol Endocrinol. 2006;4(1):18-26. http://dx.doi.org/10.1186/1477-7827-4-18. PMid:16611363.

Gao D, Bernie B. The Encyclopedia of Chinese medicine. London: Carlton; 1997.

Geva E, Jaffe RB. Role of vascular endothelial growth factor in ovarian physiology and pathology. Fertil Steril. 2000;74(3):429-38. http://dx.doi.org/10.1016/S0015-0282(00)00670-1. PMid:10973633. 
Grabowska W, Sikora E, Bielak-Zmijewska A. Sirtuins, a promising target in slowing down the ageing process. Biogerontology. 2017;18(4):447-76. http://dx.doi.org/10.1007/s10522-017-9685-9. PMid:28258519.

Ha CS, Joo BS, Kim SC, Joo JK, Kim HG, Lee KS. Estrogen administration during superovulation increases oocyte quality and expressions of vascular endothelial growth factor and nitric oxide synthase in the ovary. J Obstet Gynaecol Res. 2010;36(4):789-95. http://dx.doi.org/10.1111/j.1447-0756.2010.01212.x. PMid:20666947.

He DY, Dai SM. Anti-inflammatory and immunomodulatory effects of paeonialactiflorapall., a traditional Chinese herbal medicine. Front Pharmacol. 2011;2:10. http://dx.doi.org/10.3389/fphar.2011.00010. PMid:21687505.

Hsueh AJ, Kawamura K, Cheng Y, Fauser BC. Intraovarian control of early folliculogenesis. Endocr Rev. 2015;36(1):1-24. http://dx.doi.org/10.1210/er.2014-1020. PMid:25202833.

Jablonka-Shariff A, Olson LM. The role of nitric oxide in oocyte meiotic maturation and ovulation: meiotic abnormalities of endothelial nitric oxide synthase knock-out mouse oocytes. Endocrinology. 1998;139(6):2944-54. http://dx.doi.org/10.1210/endo.139.6.6054. PMid:9607805.

Jia W, Wang X, Xu D, Zhao A, Zhang Y. Common traditional Chinese medicinal herbs for dysmenorrhea. Phytother Res. 2006;20(10):819-24. http://dx.doi.org/10.1002/ptr.1905. PMid:16835873.

Kim N, Park KR, Park IS, Park YH. Application of novel HPLC method to the analysis of regional and seasonal variation of the active compounds in Paeonia lactiflora. Food Chem. 2006;96(3):496-502. http://dx.doi.org/10.1016/j.foodchem.2005.04.011.

Lee SC, Kwon YS, Son KH, Kim HP, Heo MY. Antioxidative constituents from Paeonia lactiflora. Arch Pharm Res. 2005;28(7):775-83. http://dx.doi.org/10.1007/BF02977342. PMid:16114491.

Lee YH, Kim B, Kim S, Kim MS, Kim H, Hwang SR, Kim K, Lee JH. Characterization of metabolite profiles from the leaves of green perilla (Perillafrutescens) by ultra-high performance liquid chromatography coupled with electrospray ionization quadrupole time-of-flight mass spectrometry and screening for their antioxidant properties. Yao Wu Shi Pin Fen Xi. 2017;25(4):776-88. http://dx.doi.org/10.1016/j.jfda.2016.09.003. PMid:28987353.

Li J, Kawamura K, Cheng Y, Liu S, Klein C, Liu S, Duan EK, Hsueh AJ. Activation of dormant ovarian follicles to generate mature eggs. Proc Natl Acad Sci USA. 2010;107(22):10280-4. http://dx.doi.org/10.1073/pnas.1001198107. PMid:20479243.

Li PP, Liu DD, Liu YJ, Song SS, Wang QT, Chang Y, Wu YJ, Chen JY, Zhao WD, Zhang LL, Wei W. BAFF/BAFF-R involved in antibodies production of rats with collagen-induced arthritis via PI3K-Akt-mTOR signaling and the regulation of paeoniflorin. J Ethnopharmacol. 2012;141(1):290-300. http://dx.doi.org/10.1016/j.jep.2012.02.034. PMid:22391142.

Liu DF, Wei W, Song LH. Protective effect of paeoniflorin on immunological liver injury induced by bacillus Calmette-Guerin plus lipopolysaccharide: modulation of tumour necrosis factor-alpha and interleukin-6 MRNA. Clin Exp Pharmacol Physiol. 2006;33(4):332-9. http://dx.doi.org/10.1111/j.14401681.2006.04371.x. PMid:16620297.

Liu M, Yin Y, Ye X, Zeng M, Zhao Q, Keefe DL, Liu L. Resveratrol protects against age-associated infertility in mice. Hum Reprod. 2013;28(3):707-17. http://dx.doi.org/10.1093/humrep/des437. PMid:23293221.

Liu WJ, Zhang XM, Wang N, Zhou XL, Fu YC, Luo LL. Calorie restriction inhibits ovarian follicle development and follicle loss through activating SIRT1 signaling in mice. Eur J Med Res. 2015;20(1):22. http://dx.doi.org/10.1186/s40001-015-0114-8. PMid:25889584.

Luciano AM, Franciosi F, Dieci C, Lodde V. Changes in large-scale chromatin structure and function during oogenesis: a journey in company with follicular cells. Anim Reprod Sci. 2014;149(1-2):3-10. http://dx.doi.org/10.1016/j.anireprosci.2014.06.026. PMid:25028181.

Luo LL, Huang J, Fu YC, Xu JJ, Qian YS. Effects of tea polyphenols on ovarian development in rats. J Endocrinol Invest. 2008;31(12):1110-8. http://dx.doi.org/10.1007/BF03345661. PMid:19246979.

May-Panloup P, Boucret L, Chao de la Barca JM, Desquiret-Dumas V, Ferré-L'Hotellier V, Morinière C, Descamps P, Procaccio V, Reynier P. Ovarian ageing: the role of mitochondria in oocytes and follicles. Hum Reprod Update. 2016;22(6):725-43. http://dx.doi.org/10.1093/humupd/dmw028. PMid:27562289.

McGee EA, Hsueh AJ. Initial and cyclic recruitment of ovarian follicles. Endocr Rev. 2000;21(2):200-14. http://dx.doi.org/10.1210/er.21.2.200. PMid:10782364.

Meldrum DR. Aging gonads, glands, and gametes: immutable or partially reversible changes? Fertil Steril. 2013;99(1):1-4. http://dx.doi.org/10.1016/j.fertnstert.2012.10.044. PMid:23164538. 
Murohara T, Horowitz JR, Silver M, Tsurumi Y, Chen D, Sullivan A, Isner JM. Vascular endothelial growth factor/vascular permeability factor enhances vascular permeability via nitric oxide and prostacyclin. Circulation. 1998;97(1):99-107. http://dx.doi.org/10.1161/01.CIR.97.1.99. PMid:9443437.

Nargund G, Doyle PE, Bourne TH, Parsons JH, Cheng WC, Campbell S, Collins WP. Ultrasound derived indices of follicular blood flow before HCG administration and the prediction of oocyte recovery and preimplantation embryo quality. Hum Reprod. 1996;11(11):2512-7. http://dx.doi.org/10.1093/oxfordjournals.humrep.a019150. PMid:8981146.

Ong M, Cheng J, Jin X, Lao W, Johnson M, Tan Y, Qu X. Paeoniflorin extract reverses dexamethasoneinduced testosterone over-secretion through downregulation of cytochrome P450 17A1 expression in primary murine theca cells. J Ethnopharmacol. 2019;229:97-103. http://dx.doi.org/10.1016/j.jep.2018.09.006. PMid:30195059.

Oyungerel S, Batzaya G, Byamba-Yondon G, Lyankhua B, Ochgerel N, Usukhjargal D. Seasonal variation of some bioactive compounds and physiological characteristics in peony (Paeonia lactiflora Pall.). Mong J Biol Sci. 2017;15(1-2):47-51. http://dx.doi.org/10.22353/mjbs.2017.15.06.

Özcan P, Fıçıcıoğlu C, Kizilkale O, Yesiladali M, Tok OE, Ozkan F, Esrefoglu M. Can coenzyme Q10 supplementation protect the ovarian reserve against oxidative damage?? J Assist Reprod Genet. 2016;33(9):1223-30. http://dx.doi.org/10.1007/s10815-016-0751-z. PMid:27255570.

Parker S, May B, Zhang C, Zhang AL, Lu C, Xue CC. A pharmacological review of bioactive constituents of Paeonia lactiflora Pallas and Paeonia veitchii Lynch. Phytother Res. 2016;30(9):1445-73. http://dx.doi.org/10.1002/ptr.5653. PMid:27279421.

Paulini F, Melo EO. The role of oocyte-secreted factors GDF9 and BMP15 in follicular development and oogenesis. Reprod Domest Anim. 2011;46(2):354-61. http://dx.doi.org/10.1111/j.14390531.2010.01739.x. PMid:21198974.

Shimizu T, Jiang JY, Iijima K, Miyabayashi K, Ogawa Y, Sasada H, Sato E. Induction of follicular development by direct single injection of vascular endothelial growth factor gene fragments into the ovary of miniature glits. Biol Reprod. 2003;69(4):1388-93. http://dx.doi.org/10.1095/biolreprod.103.016311. PMid:12826586.

Steiner AZ, Pritchard D, Stanczyk FZ, Kesner JS, Meadows JW, Herring AH, Baird DD. Association between biomarkers of ovarian reserve and infertility among older women of reproductive age. JAMA. 2017;318(14):1367-76. http://dx.doi.org/10.1001/jama.2017.14588. PMid:29049585.

Takeuchi T, Nishii O, Okamura T, Yaginuma T. Effect of paeoniflorin, glycyrrhizin and glycyrrhetic acid on ovarian androgen production. Am J Chin Med. 1991;19(1):73-8. http://dx.doi.org/10.1142/S0192415X91000119. PMid:1897494.

Tatone C, Amicarelli F, Carbone MC, Monteleone P, Caserta D, Marci R, Artini PG, Piomboni P, Focarelli R. Cellular and molecular aspects of ovarian follicle ageing. Hum Reprod Update. 2008;14(2):131-42. http://dx.doi.org/10.1093/humupd/dmm048. PMid:18239135.

Tatone C, Di Emidio G, Barbonetti A, Carta G, Luciano AM, Falone S, Amicarelli F. Sirtuins in gamete biology and reproductive physiology: emerging roles and therapeutic potential in female and male infertility. Hum Reprod Update. 2018;24(3):267-89. http://dx.doi.org/10.1093/humupd/dmy003. PMid:29447380.

Thouas GA, Trounson AO, Jones GM. Effect of female age on mouse oocyte developmental competence following mitochondrial injury. Biol Reprod. 2005;73(2):366-73. http://dx.doi.org/10.1095/biolreprod.105.040956. PMid:15843494.

Ushiroyama T, Ikeda A, Sakai M, Hosotani T, Suzuki Y, Tsubokura S, Ueki M. Effects of unkei-to, an herbal medicine, on endocrine function and ovulation in women with high basal levels of luteinizing hormone secretion. J Reprod Med. 2001;46(5):451-6. PMid:11396371.

Vachharajani VT, Liu T, Wang X, Hoth JJ, Yoza BK, McCall CE. Sirtuins link inflammation and metabolism. J Immunol Res. 2016;2016:8167273. http://dx.doi.org/10.1155/2016/8167273. PMid:26904696.

Wang J, Qian X, Gao Q, Lv C, Xu J, Jin H, Zhu H. Quercetin increases the antioxidant capacity of the ovary in menopausal rats and in ovarian granulosa cell culture in vitro. J Ovarian Res. 2018;11(1):51. http://dx.doi.org/10.1186/s13048-018-0421-0. PMid:29929541.

Wu D, Chen J, Zhu H, Xiong XG, Liang QH, Zhang Y, Zhang Y, Wang Y, Yang B, Huang X. UPLC-PDA determination of paeoniflorin in rat plasma following the oral administration of Radix Paeoniae Alba and its effects on rats with collagen-induced arthritis. Exp Ther Med. 2014;7(1):209-17. http://dx.doi.org/10.3892/etm.2013.1358. PMid:24348792. 
Yang J, Hu L, Cai T, Chen Q, Ma Q, Yang J, Meng C, Hong J. Purification and identification of two novel antioxidant peptides from perilla (Perilla frutescens $\mathrm{L}$. Britton) seed protein hydrolysates. PLoS One. 2018;13(7):e0200021. http://dx.doi.org/10.1371/journal.pone.0200021. PMid:29985955.

Zelezni AJ, Schuler HM, Reichert LJr. Gonadotropin-binding sites in the rhesus monkey ovary: role of the vasculature in the selective distribution of human chorionic gonadotropin to the preovulatory follicle. Endocrinology. 1981;109(2):356-62. http://dx.doi.org/10.1210/endo-109-2-356. PMid:6265188.

Zhou XL, Xu J, Ni YH, Chen XC, Zhang HX, Zhang XM, Liu WJ, Luo LL, Fu YC. SIRT1 activator (SRT1720) improves the follicle reserve and prolongs the ovarian lifespan of diet-induced obesity in female mice via activating SIRT1 and suppressing mTOR signaling. J Ovarian Res. 2014;7(1):97. http://dx.doi.org/10.1186/s13048-014-0097-z. PMid:25330910.

Zhu S, Yu X, Wu Y, Shiraishi F, Kawahara N, Komatsu K. Genetic and chemicalcharacterization of white and red peony root derived from Paeonia lactiflora. J Nat Med. 2015;69(1):35-45. http://dx.doi.org/10.1007/s11418-014-0857-5. PMid:25151277.

\section{Author contributions}

MJP and SEH: Conceptualization, Writing - original draft, Data curation; HJK, JH and HJC: Methodology, Data curation; KTH, SWY and SCK: Formal analysis, Funding acquisition; KSL: Conceptualization, Writing - review \& editing;CWK and BSJ: Conceptualization, Supervision, Writing - review \& editing. 